eventually made their names as mathematicians and teachers.

In this special issue, a celebration of 100 years of the Gazette, the editor. Steve Abbott, has brought together new articles in the traditional style. Many of our foremost contributors have taken the opportunity to write on matters close to their hearts. Whether they be pieces of criticism, of history, of mathematics or of polemic. I am sure you will enjoy reading the articles as much as the authors have enjoyed writing them and that our special edition will take its honoured place as :

Volume 80: Number $487 \quad$ March 1996.

ROY ASHLEY, President 1995-96

Wootton Upper School, Hall End Road, Wootton MK43 9HT

\title{
Editorial
}

The preparation of this issue has been a labour of love. I began in 1994 by approaching past Presidents of the Association and prominent mathematical writers with a request for contributions. I had surprisingly few refusals and even fewer who failed to deliver the promised articles. This reliability was more than a little problematic since I had over-ordered. I even responded to one apologetic former President with grateful thanks for a shorter than expected article.

This commemorative issue contains three special sections which have forced the exclusion of all book reviews. The opening section is concerned with the Gazette in particular and the Mathematical Association in general. Biographies of the contributors are scattered through this and the other sections. The next section deals with developments in Mathematics during the Gazette's history. It is not possible to cover all advances in the subject, and many important branches had to be left out. The resulting selection reflects the interests of those I approached. The extract from Jean Dieudonné's book Mathematics - the music of reason is an attempt to cover some of the neglected topics. The third special section consists of articles on the teaching of Mathematics - partly looking back and partly looking forward.

The remaining articles and notes are intended to be more representative of the regular Gazette style. Many of the authors wrote by invitation, which is unusual for the Gazette but otherwise I selected works by those 'old hands' whose work has graced the pages over the years.

The many photographs in this issue were culled from a variety of sources. I would like to thank Paul Halmos and the American Mathematical Society for allowing me to reproduce a number of photographs from Paul's book I have a photographic memory; Springer-Verlag for granting permission to use photographs from their publications and The London Mathematical Society for photographs from its archive. I must also thank Don Albers, Chandler Davis, John Fauvel, Dennis Lindley, Susan Oakes 
and Karen Parshall for their help in suggesting sources of photographs.

The cover picture for this issue was produced by Nick Mee of Virtual Image Ltd. I asked him for a knot design based on the pentagon motif used in the Mathematical Association crest, which has been restored to the front cover, along with capital letters last used in 1966.

The task of editing the Gazette is made much easier by the many people who help behind the scenes. The volunteers who write reports on articles for me and offer advice to contributors are too numerous to mention here, but I would like to thank them for their efforts. The proof-readers, Colin Davis and Keith Barnett and the indexer, Ernest Long are rarely mentioned; their assistance is invaluable. Mike Farrell, Claire Oliphant and the staff at Leicester Printers are unfailingly helpful, as are the staff at Association Headquarters. Finally, both Bill Richardson and I both owe a debt of gratitude to our families for their patience and forbearance. I would therefore like to finish by thanking my wife Barbara, daughters Katherine and Helen and Krys Richardson for their contributions to this special issue.

STEVE ABBOTT

\section{Producing the Gazette}

When Steve asked if I would make a contribution to this issue I hesitated, and then, as usual, said 'Yes'. Looking back, I suppose I inherited my link with the MA from my father (identical name and hair 'style' but older!). I have no idea when he joined but the earliest Gazettes on my shelves date from 1955. I have just been browsing through these:- Editor T. A. A. Broadbent, cost 5s $6 \mathrm{~d}(271 / 2 \mathrm{p})$. Among the names of the contributors are D. A. Quadling, E. C. Zeeman, T. J. Fletcher and many others. There are as many names as appear in the Gazette under the present editor. It is likely that, even allowing for the four issues, the total number of pages in 1955 was about 350, well short of the 640 in 1995. But what about the quality? I leave it to others to respond to that question!

Whilst I have been a member for some 30 years I only became 'active' in 1985. The precise dating is because that was the year the annual conference was in Dundee. I went because I felt it would never come closer and have been to all the conferences since. I have tried to help the Association in different ways but it is in my role as 'Production Editor' rather than any other Association activity (present or impending) that I write this. I do not know enough about 'traditional printing methods' to do more than speculate on the processes which went on in making a Gazette in 1955 or earlier. I expect that it was a very involved process with typed copy, possibly retyped etc, with mathematical notation written in - considerably different to the process which resulted in the Gazette in your hands as you read this.

The current system, begun by Nick MacKinnon but now developed 